\title{
Efeito do ácido mefenâmico sobre a mobilidade embrionária em éguas
}

Veridiana de Paula Andrade, Carolina Tiemi Cardoso Okada, Camila Paula Freitas-Dell’Aqua, Marco Antonio Alvarenga

Faculdade de Medicina Veterinária e Zootecnia, Universidade Estadual Paulista (UNESP), Botucatu, SP, Brasil

*Autor correspondente

e-mail: vet_veriandrade@hotmail.com

\section{Resumo}

Na espécie equina a mobilidade ocorre entre os dias 6 e 16 após a ovulação, e nesta fase o embrião apresenta formato esférico e se desloca constantemente pelo ambiente uterino através das contrações miometrais produzidas por estímulos químicos da própria vesícula embrionária. Este longo período de estímulo assegura que o embrião produza sinais antiluteolíticos para o endométrio, evitando assim o processo de luteólise. Após 17 dias, encerra-se o evento, culminando com a fixação do embrião em um dos cornos. Durante a mobilidade, a vesícula embrionária equina produz prostaglandinas PGE-2, PGF e PG1-2. Frequentemente no momento da técnica de transferência de embrião, faz-se o uso de medicamentos anti-inflamatórios não esteroidais (AINEs) na tentativa de reduzir inflamação uterina e geração de PGF2 $\alpha$ pelo endometrio. Se ocorrer alguma falha durante a migração embrionária, o reconhecimento materno da gestação pode ser afetado e consequentemente lise do corpo lúteo, resultando em morte precoce do embrião. 0 trabalho tem como objetivo avaliar o efeito do ácido mefenamico (AM) em relação à migração embrionária: AM é um inibidor da ciclooxigenase 1 e 2 (COX-1 e COX-2). Baseado no estudo de Ginther (1998), o útero foi dividido em nove segmentos representados em desenho esquemático, e após a vesícula ser localizada, a mesma era registrada no local correspondente. No presente experimento foram utilizadas 10 éguas, as quais foram avaliadas pelo método de ultrassonografia transretal seriada a cada 5 minutos durante uma hora. A primeira avaliação foi determinada como controle e a segunda avaliação foi realizada após duas horas da administração do AM, tempo suficiente para o medicamento atingir o pico sérico. Depois de 24 horas da administração do AM, as éguas foram reavalidas por palpação seriada durante mais uma hora, a fim de verificar se a droga apresentaria efeito residual na mobilidade embrionária. Primeiramente realizou-se uma análise descritiva dos parâmetros (média e erro padrão) de acordo com as condições experimentais e avaliação da normalidade pelo teste Kolmogorov-Smirnov. Como os dados foram não paramétricos, 
utilizou-se o teste de Friedman seguido por Dunn's. 0 uso do AM diminuiu $(P<0.05)$ a quantidade de movimentos por hora realizados pelo embrião, de $6.0 \pm 0.3$ no controle para $2.7 \pm 0.3$ no grupo tratado. Na ultrassonografia seriada 24 horas após o tratamento, foi observado padrão semelhante ao controle, $5.2 \pm$ 0.4 , demonstrando que a mobilidade voltou ao padrão de movimentos observados no momento controle. Com esse estudo, podemos concluir que a aplicação do AM durante o período de mobilidade embrionária diminuiu em média 55\% a mobilidade embrionária. Não foi observado efeito remanescente do AM 24 horas após sua administração.

Palavras-chave: Anti-inflamatório não esteroidal. Mobilidade embrionária. Égua. 